\title{
Pengaruh Subtitusi Tepung Biji Bunga Matahari (Helianthus annuus L.) Dalam Pakan Komersial Dengan Konsentrasi Tertentu Terhadap Performa Ayam Pedaging
}

\section{(EFFECT OF SUBTITUTION OF SUNFLOWER SEED FLOWER (Helianthus annuus L.) IN COMMERCIAL FEED WITH CERTAIN CONCENTRATION ON BROILER CHICKEN PERFORMANCE)}

\author{
Beta Hermansyah $^{1 *}$, Widya Paramita Lokapirnasari ${ }^{2}$, Faisal Fikri ${ }^{3}$ \\ ${ }^{1}$ Bachelor of Veterinary Medicine, \\ ${ }^{2}$ Department of Animal Nutrition, \\ ${ }^{3}$ Department of Veterinary Science, \\ Faculty of Veterinary Medicine, Universitas Airlangga, \\ UNAIR C-Campus Mulyorejo, Surabaya, Jawa Timur, Indonesia, 60115 \\ Telp. (031)5993016, Fax. (031)5993015 \\ *Corresponding author: beta.hermansyah-2014@ @kh.unair.ac.id
}

\begin{abstract}
Abstrak
Penelitian ini bertujuan untuk mengetahui pengaruh penggantian tepung biji bunga matahari (Helianthus anпииs L.) di pakan komersial dengan konsentrasi tertentu pada kinerja ayam pedaging. Penelitian ini menggunakan desain acak lengkap. Sampel terdiri dari 20 ekor ayam broiler dibagi secara acak menjadi 5 kelompok. Perlakuan adalah P1, P2, P3, dan P4 masing-masing CP511 pakan komersial yang mengandung tepung biji bunga matahari $25 \%, 30 \%, 35 \%$, dan $40 \%$ serta kontrol tanpa substitusi P0 tepung biji bunga matahari. Variabel yang digunakan adalah konsumsi pakan, bobot akhir dan konversi pakan kemudian hasilnya dianalisis dengan Analisis Varians. Hasil yang diperoleh rata-rata nilai konsumsi pakan P0 adalah 79,76 gram, P1 adalah 77,90 gram, P2 adalah 77,35 gram, P3 adalah 77,98 gram, P4 adalah 77,58 gram. Hasil nilai rata-rata berat akhir 1545,5 gram yaitu P0, P1 adalah 1296,5 gram, P2 1325,75 gram, P3 1256 gram, P4 1203 gram. Hasil yang diperoleh dari nilai rata-rata konversi pakan adalah P0 1,37, P1 1,69, P2 1,61, P3 1,71, P4 1,88. Berdasarkan hasil dapat disimpulkan bahwa substitusi tepung biji bunga matahari dalam diet komersial tidak meningkatkan asupan pakan, berat badan dan dapat meningkatkan konversi pakan.
\end{abstract}

Kata kunci: subtitusi pakan, Helianthus annuus L, performa ayam pedaging

\section{Abstract}

This study aims to determine the effect of substituting flour sunflower seeds (Helianthus annuus L.) in commercial feed with a particular concentration on broiler's performance. This study used a completely randomized design. The sample consisted of 20 broiler chickens were divided randomly into 5 groups. The treatments were P1, P2, P3, and P4 respectively CP511 commercial feed containing sunflower seed flour $25 \%$, $30 \%, 35 \%$, and $40 \%$ as well as a control without substitution P0 flour sunflower seeds. The variable used is the feed consumption, final weight and feed conversion and then the results are analyzed by Analysis of Variance. Results obtained an average feed consumption value P0 is 79.76 grams, $P 1$ is 77.90 grams, $P 2$ is 77.35 grams, $P 3$ is 77.98 grams, P4 is 77.58 grams. The results of the average value of the final weight of 1545.5 grams namely $P 0, P 1$ is 1296.5 grams, $P 2$ is 1325.75 grams, is 1256 grams P3, P4 is 1203 grams. Results obtained from the average value of feed conversion is P0 1.37, P1 is 1.69, P2 is 1.61, P3 is 1.71, P4 is 1.88. Based on the results it can be concluded that the substitution of sunflower seed flour in commercial diets not increase feed intake, body weight and can increase feed conversion.

Key words: feed subtitution, Helianthus annuus L, broiler performance 


\section{PENDAHULUAN}

Ayam pedaging merupakan hasil rekayasa teknologi yang memiliki karakteristik ekonomis. Ayam pedaging memiliki ciri khas yaitu pertumbuhan cepat, penghasil daging, masa panen pendek, daging yang berserat lunak, timbunan daging yang baik, dada lebih lebar dan berkulit licin (Nastiti, 2015).

Perkembangan usaha ayam pedaging mencakup berbagai faktor yang berkaitan. Peranan pakan merupakan faktor yang sangat penting untuk meningkatkan efisiensi produktifitas karena $60 \%$ dari biaya produksi adalah untuk pakan (Sari dkk., 2004). Besarnya biaya produksi yang dibutuhkan menyebabkan para peternak harus mencari bahan ransum alternatif yang lebih murah, mudah didapat, dan mempunyai gizi yang cukup.

Keberhasilan dari usaha ayam pedaging yang dipelihara secara intensif sangat tergantung pada ketersediaan bahan pakan murah, dan mampu memenuhi kebutuhan zat nutrisi ayam pedaging (Sindu, 2010). Pakan dapat ditekan serendah dan seefisien mungkin tanpa berpengaruh buruk terhadap performa, produksi dan fisiologis maka usaha ternak ayam pedaging dapat memberikan keuntungan sebagai sumber pendapatan masyarakat (Sari dkk., 2004).

Alternatif bahan pakan lokal yang dapat digunakan sebagai pengganti sumber protein nabati, mempunyai kandungan protein tergolong tinggi, dan ketersediaanya cukup yaitu biji bunga matahari. Biji bunga matahari merupakan sumber nutrisi yang potensial dengan kandungan protein $21 \%$, lemak $55 \%$ dan karbohidrat $19 \%$. Kandungan minyak sebanyak $40-50 \%$ dari berat biji bunga matahari (Gandhi et al., 2005). Taiwo et al. (2005) juga menyatakan bahwa tepung biji bunga matahari memiliki nutrisi yang berpotensi untuk bahan pakan ternak karena mengandung protein yang tinggi setara dengan biji kapas, kedelai dan kacang tanah.

Berdasarkan pernyataan di atas, maka penelitian mengenai konsumsi pakan, konversi pakan dan berat badan akhir ayam pedaging yang disubtitusi pakan tepung biji bunga matahari (Helianthus Annuus L) perlu dilakukan, sehingga dapat memberikan informasi mengenai efisiensi pemanfaatan bahan pakan alternatif tepung biji bunga matahari untuk pemenuhan kebutuhan protein pedaging.

\section{METODE PENELITIAN}

\section{Alat dan Bahan}

Hewan coba yang digunakan dalam penelitian ini adalah 20 ekor ayam pedaging strain Cobb CP 707 dari PT. Charoen Pokphand Indonesia yang telah berumur 14 hari dengan berat badan antara 400-500 g dan dipilih yang berjenis kelamin jantan.

Bahan pakan yang digunakan yaitu pakan komersial dengan merk dagang CP 511 dan tepung biji bunga matahari dengan konsentrasi dalam pakan CP 511 sebanyak 25\%, 30\%, 35\% dan 40\%. Desinfektan untuk mendesinfeksi kandang dan peralatan kandang sebelum ayam pedaging masuk. Air minum diberikan secara adlibitum menggunakan air yang bersumber dari PDAM dan ditambahkan dengan vitachick dengan dosis untuk anak ayam umur 0-2 minggu sebanyak 5g/7liter/hari, umur 3-4 minggu sebanyak $5 \mathrm{~g} / 12$ liter/hari dan umur 5 minggudewasa sebanyak $5 \mathrm{~g} / 7$ liter/hari.

\section{Pembuatan Tepung Biji Bunga Matahari}

Pembuatan tepung biji bunga matahari dilakukan dengan cara menjemur biji bunga matahari terlebih dahulu selama kurang lebih 6 jam agar mudah untuk digiling, setelah itu digiling dengan mesin giling sampai halus. Biji bunga matahari yang telah menjadi tepung kemudian dicampur dengan pakan komersial sesuai masing-masing taraf perlakuan.

\section{Perlakuan}

Setiap petak kandang dibersihkan dengan cara disapu, disikat dan dicuci dengan air bersih, kemudian disemprot dengan larutan desinfektan. Desinfektan menggunakan merek ASK (Air Steril Kandang) 37 PLUS yang dicampur dengan air dengan dosis 1 liter ASK/30 liter air. Tujuan penyemprotan desinfektan adalah untuk membunuh mikroorganisme berbahaya yang merugikan. 
Kandang diberi sekam padi sebagai alas. Tempat makan dan air minum disiapkan dan dibersihkan sebelum digunakan. Setiap kandang terdapat satu tempat pakan, satu tempat minum dan satu buah lampu 5 watt yang dipasang pada tengah-tengah kandang untuk mempertahankan suhu pada kisaran $31-33^{\circ} \mathrm{C}$. Seluruh kandang ditutup plastik sebagai pelindung dari udara dingin sampai ayam berumur satu minggu.

Setiap kandang diberi nomor perlakuan dan ulangan. DOC yang baru datang diberi larutan gula $(2-5 \%)$ yang dihangatkan terlebih dahulu hingga bersuhu $20-24^{\circ} \mathrm{C}$ untuk menyediakan energi yang bisa langsung diserap oleh tubuh DOC dan bisa menggantikan energi yang banyak terkuras selama masa pengiriman. Pemberian larutan gula pada saat ayam baru datang sebanyak 2 liter larutan atau 2 tempat minum ayam penuh untuk 100 ekor ayam. Pemberian air gula hanya satu kali, setelah habis baru diberikan air minum biasa.

Lampu digunakan sebagai pemanas sekaligus penerangan dan dinyalakan selama 24 jam sampai ayam berumur dua minggu. Ketinggian lampu sebagai pemanas diukur setinggi kepala DOC atau sekitar $10 \mathrm{~cm}$ dari lantai kandang. Lampu berfungsi sebagai penerangan saat ayam berumur dua minggu lebih dan ketinggian lampu diubah menjadi dua meter dari alas kandang. Lampu sebagai penerangan hanya dinyalakan saat malam hari saja. Ransum diberikan sebanyak dua kali sehari sesuai dengan taraf masing-masing perlakuan. Pemberian pakan setiap hari pada waktu pagi dan sore hari.
Tempat pakan dan air minum selalu dibersihkan saat penambahan pakan maupun air minum.

Penimbangan dilakukan pada awal pemberian perlakuan (umur 14 hari) untuk mengetahui berat awal ayam pedaging. Penimbangan berat badan akhir ayam pedaging dilakukan pada saat umur 35 hari. Pencegahan penyakit dilakukan dengan pemberian vaksin ND melalui tetes mata, saat umur ayam 4 hari. Ayam umur 21 hari dilakukan vaksin ND tahap kedua yang diberikan secara injeksi intra muskuler.

\section{Analisis Data}

Rataan hasil perhitungan dari setiap variabel tergantung dianggap sebagai data yang didapat dan dilakukan analisis parametrik menggunakan Sidik Ragam atau Analysis of Variance satu arah dan bila berbeda nyata $(\mathrm{p}<0,05)$ dilanjutkan dengan uji Duncan (Al Arif, 2016). Seluruh proses analisis dikerjakan dengan program SPSS.

\section{HASIL DAN PEMBAHASAN}

Berdasarkan hasil Analysis of Variance (ANOVA) dan dilanjutkan dengan Uji Jarak Berganda Duncan didapatkan hasil antara P0 dengan P1, P2, P3, dan P4 menunjukkan hasil yang berbeda nyata $(\mathrm{p}<0.05)$ sedangkan untuk antar perlakuan yang ditambahkan tepung biji bunga matahari pada pakan yaitu P1 (25\%), P2 (30\%), P3 (35\%), dan P4 (40\%) menunjukkan hasil yang tidak berbeda nyata $(\mathrm{p}>0.05)$.

Tabel 1. Rata-rata dan simpangan baku perlakuan terhadap konsumsi, berat akhir dan FCR

\begin{tabular}{cccc}
\hline \multirow{2}{*}{ Perlakuan } & \multicolumn{3}{c}{ Rata-rata \pm SD } \\
\cline { 2 - 4 } & Konsumsi & Berat akhir & FCR \\
\hline P0 & $79,76^{b} \pm 1,17$ & $1545,50^{a} \pm 54,47$ & $1,37^{a} \pm 0,06$ \\
P1 & $77,90^{a} \pm 1,52$ & $1296,50^{a b} \pm 102,36$ & $1,69^{b c} \pm 0,20$ \\
P2 & $77,35^{a} \pm 0,85$ & $1325,75^{b} \pm 15,90$ & $1,61^{b} \pm 0,01$ \\
P3 & $77,98^{a} \pm 0,70$ & $1256,00^{a b} \pm 55,51$ & $1,71^{b c} \pm 0,19$ \\
P4 & $77,58^{a} \pm 0,78$ & $1203,00^{a} \pm 105,10$ & $1,88^{a} \pm 0,18$
\end{tabular}

Keterangan : superskrip yang berbeda pada kolom yang sama menunjukkan perbedaan nyata $(\mathrm{p}<0,05)$

P0 yang merupakan pakan komersial merk CP511 memiliki nilai rata-rata konsumsi pakan yang tertinggi yaitu 79,76 gram dibandingkan dengan P1 (25\%) dengan nilai rata-rata 77,90 
gram, P2 (30\%) dengan nilai rata-rata 77,35 gram, P3 (35\%) dengan nilai rata-rata 77,98 gram, dan P4 (40\%) dengan nilai rata-rata 77,58 gram. Penurunan konsumsi pakan ini diduga disebabkan karena adanya penambahan tepung biji bunga matahari dalam pakan P1, P2, P3, dan $\mathrm{P} 4$ sehingga dapat menurunkan palatabilitas dari pakan tersebut.

Kandungan serat kasar pada pakan perlakuan yang mengandung tepung biji bunga matahari dalam penelitian ini yaitu P1(25\%), P2(30\%), P3(35\%), P4(40\%) berturut-turut adalah $8.46 \%$, $9.11 \%, 9.77 \%$, dan $10.43 \%$. Kandungan serat kasar yang tinggi diduga menjadi penyebab turunnya palatabilitas karena menurut Soenarwiyo dan Deafania (2015), kualitas serat kasar yang baik dalam pakan ayam pedaging yaitu sekitar 4-4.5\%. Tavernari et al. (2008) juga berpendapat bahwa kandungan serat kasar yang tinggi pada biji bunga matahari menjadi penyebab turunnya palatabilitas.

Palatabilitas merupakan faktor yang menentukan tingkat konsumsi pakan pada ternak. Palatabilitas dipengaruhi oleh bentuk, bau, rasa, tekstur dan suhu makanan yang diberikan (Deviana dkk, 2018). Ayam pedaging lebih menyukai bahan-bahan makanan yang berwarna cerah (Nastiti, 2015). P0 atau pakan komersial merk CP511 memiliki warna yang lebih cerah dan bau yang lebih menyengat sedangkan tepung biji bunga matahari memiliki warna yang gelap dan bau yang tidak begitu menyengat, hal ini mungkin yang membuat perlakuan pakan komersial yang dicampur dengan tepung biji bunga matahari kurang disukai oleh ayam pedaging sehingga menyebabkan penurunan konsumsi pakan.

Berdasarkan hasil Analysis of Variance (ANOVA) menunjukkan bahwa pencampuran berbagai tingkat konsentrasi tepung biji bunga matahari dalam pakan komersial berpengaruh nyata $(p<0,05)$ terhadap berat akhir ayam pedaging. Penggunaan tepung biji bunga matahari dalam pakan komersial mulai dari taraf $25 \%$ sampai $40 \%$ menyebabkan penurunan terhadap berat akhir ayam pedaging atau lebih rendah dibandingkan dengan kontrol (P0). Ratarata nilai Berat Akhir pada ayam pedaging P0 (kontrol) adalah 1545,50 gram, sedangkan P1 (25\%) adalah 1296,50 gram, P2 (30\%) adalah 1325,75 gram, $\mathrm{P} 3$ (35\%) adalah 1256 gram, dan P4 (40\%) adalah 1203 gram.

Kandungan protein pada biji bunga matahari yang lebih tinggi yang sebelumnya diduga dapat meningkatkan berat akhir ayam pedaging ternyata tidak terjadi. Hasil yang lebih buruk dari penggunaan tepung biji bunga matahari dalam pakan komersial ini mungkin disebabkan karena kandungan serat kasarnya yang tinggi. Furlan et al. (2001) menyatakan bahwa kandungan serat yang tinggi pada biji bunga matahari menyebabkan metabolisme tubuh yang buruk apabila diberikan pada hewan non ruminansia dan akan mengakibatkan performa hidup yang buruk.

Kandungan serat kasar yang tinggi membuat pakan sulit untuk dicerna oleh saluran pencernaan ayam pedaging sehingga pemanfaatan kandungan dalam pakan untuk pertumbuhan ayam pedaging menjadi kurang maksimal (Agustono dkk, 2017). Konsumsi pakan juga berpengaruh terhadap pertumbuhan berat badan ayam pedaging. Semakin banyak konsumsi pakan semakin banyak pula energi yang dihasilkan untuk pertumbuhan, namun pada pakan perlakuan yang dicampur dengan tepung biji bunga matahari (P1, P2, P3, dan P4) memiliki nilai berat akhir yang lebih rendah dari kontrol (P0) karena konsumsi pakannya menurun sehingga energi yang dihasilkan untuk pertumbuhan juga lebih sedikit.

Berdasarkan hasil Analysis of Variance (ANOVA) menunjukkan bahwa pencampuran berbagai tingkat konsentrasi tepung biji bunga matahari dalam pakan komersial berpengaruh nyata $(\mathrm{p}<0,05)$ terhadap konversi ransum ayam pedaging. Konversi ransum berkaitan dengan konsumsi pakan dan penambahan berat badan. Konversi ransum pada P0, P1, P2, P3, dan P4 berturut-turut adalah 1,$37 ; 1,69 ; 1,61 ; 1,71$; 1,88 .

Nilai rata-rata konversi ransum pada perlakuan pakan yang disubtitusi dengan tepung biji bunga matahari lebih tinggi dari pada perlakuan pakan kontrol. Meningkatnya konversi ransum ini mungkin disebabkan karena 
kandungan serat kasar yang tinggi, sehingga pakan yang dikonsumsi tidak seluruhnya dapat dicerna dan diserap oleh sistem pencernaan ayam pedaging.

James (2004) dan Saputro, dkk (2018) menyatakan bahwa nilai konversi pakan dipengaruhi oleh beberapa faktor antara lain genetik, tipe pakan yang digunakan, feed additive yang digunakan dalam pakan, manajemen pemeliharaan, dan suhu lingkungan. Pakan pada perlakuan P1, P2, P3, dan P4 masing masing mengandung tepung biji bunga matahari sebesar 25\% ; 30\% ; 35\% ; 40\%. Tepung biji bunga matahari mengandung serat kasar yang tinggi. Hal ini mungkin yang menjadi penyebab pada perlakuan P1, P2, P3, dan P4 mengalami peningkatan konversi ransum.

Furlan et al. (2001) menyatakan bahwa kandungan serat yang tinggi pada biji bunga matahari menyebabkan metabolisme tubuh yang buruk apabila diberikan pada hewan non ruminansia dan akan mengakibatkan performa hidup yang buruk. Konversi ransum menggambarkan berapa ransum yang dikonsumsi untuk setiap kilogram pertambahan bobot badan. Konversi ransum merupakan tolok ukur untuk mengetahui bahwa ransum yang diberikan pada ayam telah memenuhi syarat atau belum (Wardiny, 2011).

\section{KESIMPULAN}

Tepung biji bunga matahari yang disubtitusi dalam pakan komersial tidak dapat meningkatkan performa ayam pedaging.

\section{UCAPAN TERIMA KASIH}

Terimakasih kepada Fakultas Kedokteran Hewan Universitas Airlangga yang telah menfasilitasi penelitian sehingga dapat berjalan dengan baik.

\section{DAFTAR PUSTAKA}

Agustono, B., Lamid, M., Ma'ruf, A., Purnama, M.T.E. 2017. Identifikasi Limbah Pertanian dan Perkebunan sebagai Bahan Pakan
Inkonvensional di Banyuwangi. Jurnal Medik Veteriner, 1(1), 12-22.

Deviana, D., Cahyo, N.P.D., Kumalaningrum, D. R., Kusuma, W.A., Lailiyah, F., Purnama, M.T.E. 2018. Rekayasa Konsentrat Bekatul dengan Tepung Jantung Pisang Dapat Meningkatkan Berat Badan dan Menurunkan Kadar Kolesterol Kambing. Jurnal Sain Veteriner, 36(1), 74-79.

Furlan, A.C., Mantovani, C., Murakami, A.E., Moreira, I., Scapinello, C., Martins, E.N. 2001. Use of Sunflower Meal in Feed for Broilers. J. Anim. Sci., 30, 158-164.

Gandhi, S.D., Heesacker, A.F., Freeman, C.A., Argyris, J., Bradford, K., Knapp, S.J. 2005. The Self-incompatibility locus (S ) and Quantitative Trait Loci for Self-pollination and Seed Dormancy in Sunflower. Original Paper Springer-Verlag, 111, 619-629.

James, R.G. 2004. Modern Livestock and Poultry Production. 7th edn. Thomson Delmar Learning Inc., FFA Activities, London.

Nastiti, R. 2015. Menjadi Milyader Budidaya Ayam Broiler. Pustaka Baru Press. Yogyakarta.

Saputro, A.L., Hamid, I.S., Prastiya, R.A., Purnama, M.T.E. 2018. Hidroponik Fodder Jagung sebagai Substitusi Hijauan Pakan Ternak Ditinjau dari Produktivitas Susu Kambing Sapera. Jurnal Medik Veteriner, 1(2), 48-51.

Sari, M.L., Sandi, S., Mega, O. 2004. Konsumsi dan Konversi Pakan Ayam Pedaging Bibit Periode Pertumbuhan dengan Perlakuan Pembatasan Pakan pada Lantai Kawat dan Litter. J. Indon. Trop. Anim. Agric., 29, 8690. 
Soenarwiyo, W.S. dan Deafania. 2015. Kunci Sukses Budidaya Ayam Broiler. Araska. Yogyakarta.

Sindu, A. 2010. Pengaruh Pemberian Probiotik Temban, Biovet dan Biolacta Terhadap Persentase Karkas, Bobot Lemak Abdomen dan Organ Dalam Ayam Broiler. Jurnal Sains dan Teknologi Indonesia, 12, 53-59.

Taiwo, A.A., Adejuyigbe, A.D., Adebomale, E.A., Oshotan, J.S., David, O.O. 2005. Performance of Nutrient Digestibility of Weaned Rabbits Fed Forages Supplemented
With Concentrate. Nig. J. Anim. Prod., 32(1), $74-78$.

Tavernari, F.C. Albino, L.F.T. Morata, R.L. 2008. Inclusion of Sunflower Meal, with or without Enzyme Supplementation, in Broiler Diets. Revista Brasileira de Ciência Avícola, 10(4), 233-238.

Wardiny, T.M. 2011. Subtitusi Tepung Daun Mengkudu Dalam Ransum Meningkatkan Kinerja Ayam Broiler. Jurnal Matematika, Sains, dan Teknologi, 12(2). 